\title{
Seasonal changes in soil properties, microbial biomass and enzyme activities across the soil profile in two alpine ecosystems
}

\author{
Ying Chen ${ }^{1}$, Mengguang $\mathrm{Han}^{1}, \mathrm{Xia}$ Yuan ${ }^{1}$, Guangmin $\mathrm{CaO}^{2}$, Biao $\mathrm{Zhu}^{1}{ }^{\text {, }}$ \\ 1 Institute of Ecology, College of Urban and Environmental Sciences, and Key Laboratory for Earth Surface Processes of the Ministry of \\ Education, Peking University, Beijing 100871, China \\ 2 Key Laboratory of Adaptation and Evolution of Plateau Biota, Northwest Institute of Plateau Biology, Chinese Academy of Sciences, \\ Xining 810008, China
}

H I G H L I G H T S

- We measured soil variables along the profile in two alpine ecosystems.

- Most of soil properties decreased with depth and varied with time.

- Root and microbial biomass decreased with depth and increased with time.

- Soil enzyme activities decreased with depth but showed little change with time.

- Soil properties and microbial biomass were more dynamic than enzyme activities.

\section{ARTICLE INFO}

Article history:

Received December 21, 2020

Revised March 28, 2021

Accepted May 6, 2021

Keywords:

Seasonal variation

Soil depth

Microbial biomass

Extracellular enzyme activity

Alpine ecosystem
GRAPHICAL ABSTRACT

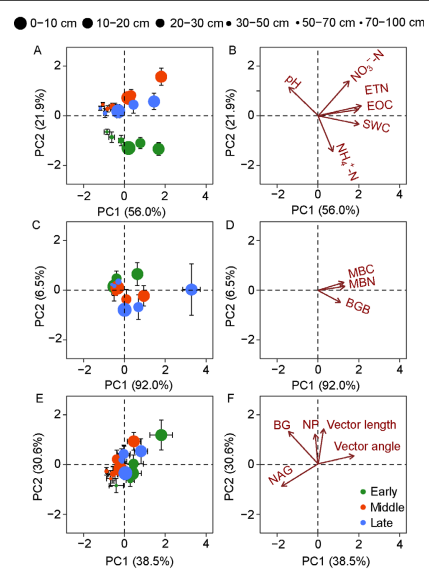

A B S T R A C T

Microbial biomass and extracellular enzyme activities control the rate of soil organic carbon decomposition, thereby affecting soil carbon pool. However, seasonal dynamics of soil microbial properties at different depths of the soil profile remain unclear. In this study, we sampled soils in the early, middle and late growing season at different soil depths $(0-100 \mathrm{~cm})$ in two alpine ecosystems (meadow and shrubland) on the Tibetan Plateau. We measured plant belowground biomass, soil properties, microbial biomass and extracellular enzyme activities. We found that soil properties changed significantly with sampling time and soil depth. Specifically, most of soil properties consistently decreased with increasing soil depth, but inconsistently varied with sampling time. Moreover, root biomass and microbial biomass decreased with increasing soil depth and increased with sampling time during the growing season. However, microbial extracellular enzyme activities and their vector properties all changed with depth, but did not vary significantly with time. Taken together, these results show that soil properties, microbial biomass and extracellular enzyme activities mostly decline with increasing depth of the soil profile, and soil properties and microbial biomass are generally more variable during the growing season than extracellular enzyme activities across the soil profile in these alpine ecosystems. Further studies are needed to investigate the changes in soil microbial community composition and function at different soil depths over the growing season, which can enhance our mechanistic understanding of whole-profile soil carbon dynamics of alpine ecosystems under climate change.

๑) Higher Education Press 2021

* Corresponding author

E-mail address: biaozhu@pku.edu.cn (B. Zhu) 


\section{Introduction}

Soils store more organic carbon than vegetation and atmosphere together, and soil carbon dynamics play an important role in the global carbon cycle (Lal, 2004; Schmidt et al., 2011). Soil extracellular enzymes are proteins that are widely distributed in the soil, which catalyze the mineralization of soil organic matter and the degradation of macromolecular organic substances that cannot be absorbed by plants and microbes into absorbable small molecular substances (Allison et al., 2010; Sinsabaugh, 2010; Stone et al., 2012; Chen et al., 2021). Thus, they play a critical and irreplaceable role in soil carbon and nutrient cycling (Burns et al., 2013; Jing et al., 2017; Chen et al., 2019).

Soil extracellular enzymes are secreted into the soil mainly by plant roots and soil microbes (Allison and Vitousek, 2004; Sinsabaugh and Shah, 2012). Generally, soil enzyme activities are used to characterize the rate of SOM decomposition and reflect the transformations of carbon, nitrogen, and phosphorus by soil microbes. There are many kinds of extracellular enzymes in the soil, and different extracellular enzymes have different functions, catalyzing different reaction stages and jointly maintaining the overall function of the ecosystem (Sinsabaugh, 2010; Burns et al., 2013). The enzymes involved in carbon cycling (e.g., BG, $\beta$-1,4-glucosidase), nitrogen cycling (e.g., NAG, $\beta-1,4-N$-acetyl-glucosaminnidase) and phosphorous cycling (e.g., phosphatase) are widely studied in experimental and meta-analysis studies (Kittredge et al., 2018; Xiao et al., 2018; Sihi et al., 2019). Furthermore, the vector properties of soil enzyme activities (vector angle and vector length) are increasingly used to characterize the energy and nutrient limitations of soil microbes (Sinsabaugh et al., 2008; Moorhead et al., 2016; Jing et al., 2020).

In the process of production, transfer, catalyzation, degradation and inactivation, soil extracellular enzymes are affected by many biotic and abiotic factors (e.g., soil temperature and moisture, $\mathrm{pH}$ and nutrient availability, microbial biomass and community composition), which change greatly across seasons within a year. Therefore, studying the seasonal dynamics of soil extracellular enzyme activities can indirectly reflect the comprehensive responses of soil microbial community structure and function to environmental changes. However, there is no consistent pattern of the seasonal dynamics of soil enzyme activities (Boerner et al., 2005; Waldrop and Firestone, 2006; Yao et al., 2011). Moreover, previous studies on soil enzyme activities and their seasonal dynamics are mainly focused on the surface soil (<20 cm) (Waldrop and Firestone, 2006; Yao et al., 2011), while those in the subsurface soils $(>20 \mathrm{~cm})$ that store more than half of the soil carbon in the top $1 \mathrm{~m}$ have been rarely measured. Given that environmental factors (e.g., temperature and moisture), soil properties (e.g., pH, total and available nutrients), and microbial communities (biomass, composition and function) all significantly vary with depth along the soil profile (Stone et al., 2015; Balesdent et al., 2018; Hou et al., 2019), soil enzyme activity should also vary with depth. For example, it has been shown that soil enzyme activities often decline with depth because of the decrease in water content, nutrient level, carbon input, and microbial biomass with increasing soil depth (Stone et al., 2014). The seasonal changes of soil extracellular enzyme activities in the surface soils are well understood, but those in the subsurface soils remain unclear (Dove et al., 2020). Therefore, studying the seasonal dynamics of soil enzyme activities at various depths of the soil profile is important to enhance our mechanistic understanding of whole-profile soil carbon dynamics under climate change (Dove et al., 2020).

The Tibetan Plateau is the highest and largest plateau in the world. As the "third pole of the earth," the alpine ecosystems on the Tibetan Plateau have polar characteristics in many aspects, such as extreme coldness, lack of oxygen, long sunshine hours, strong radiation, and low precipitation. The alpine meadow and alpine shrubland are widely distributed on the plateau, which together cover more than $40 \%$ of the total area. The densities of soil organic carbon in these alpine ecosystems are very high because of long-time biological carbon sequestration and slow microbial biodegradation (Yang et al., 2008). It is generally believed that the Tibetan Plateau is particularly sensitive to global environmental change (Piao et al., 2019; Chen et al., 2020). As the highest and largest geomorphic unit in Asia, the Tibetan Plateau plays an important role in climate change in Asia and the world (Zhang et al., 2015). Therefore, studying the seasonal dynamics of soil properties, microbial biomass and enzyme activities at different soil depths can help us better understand the effect of climate change on soil carbon and nutrient cycling in alpine ecosystems.

In this study, our objective was to explore the seasonal dynamics of soil properties, microbial biomass and extracellular enzyme activities at different soil depths $(0-100 \mathrm{~cm}$, six layers) in two alpine ecosystems (meadow and shrubland) on the Tibetan Plateau. Specifically, we hypothesized that 1) soil properties, root and microbial biomass, and soil enzyme activities in both alpine ecosystems would change greatly with soil depth and sampling time during the growing season due to concurrent changes in temperature, moisture and plant inputs, and 2) such seasonal variations in these soil variables would progressively decline with depth along the soil profile of both alpine ecosystems because seasonal changes in environmental and biotic factors also decline with depth.

\section{Materials and methods}

\subsection{Site description}

The study site was located at the Haibei National Field Research Station of Alpine Grassland Ecosystems, northeast of the Tibetan Plateau, Menyuan County, Qinghai Province, China $\left(37^{\circ} 29^{\prime}-37^{\circ} 45^{\prime} \mathrm{N}, 101^{\circ} 12^{\prime}-101^{\circ} 23^{\prime} \mathrm{E}\right.$, 
$3250 \mathrm{~m}$ a.s.I.). This area belongs to the typical plateau continental climate. The warm season (growing season) is cool and short and is from May to September (5 months), while the cold season (non-growing season) is very cold and long and is from October to April (7 months). The mean annual temperature (MAT) is $-1.1^{\circ} \mathrm{C}$. The mean temperature of the hottest month is $9.9^{\circ} \mathrm{C}$ in July and the mean temperature of the coldest month is $-15.2^{\circ} \mathrm{C}$ in January. The mean annual precipitation (MAP) is $487 \mathrm{~mm}(80 \%$ of which is distributed in the plant growing season from May to September). The daily air temperature and monthly precipitation from April to October of 2017 were obtained from the Haibei station to present the micro-climate of the three sampling times of the growing season in 2017 (Fig. S1). The soil temperature and volumetric soil water content at different soil depths from June to October in 2018 (Figs. S2, S3) were obtained from temperature (custom-made thermistors) and moisture (PR26 , Delta-T, UK) probes buried at different depths $(0-100 \mathrm{~cm})$ of the alpine meadow to show the micro-environment at different soil depths. We did not have such measurements in 2017 or in the shrubland because these probes were not available until 2018 and were only installed in the meadow.

This region has two main vegetation types: alpine meadow and alpine shrubland. The soil is classified as Mat-Cryic Cambisol in meadow and Mol-Cryic Cambisol in shrubland (Hou et al., 2019). The meadow is dominated by Stipa aliena, Elymus nutans, Gentiana straminea, Tibetia himalaica, and Kobresia humilis and other herbaceous plants. The shrubland is dominated by Potentilla fruticose, Rhododendron simsii, Salix oritrepha, Kobresia myosuroides, Festuca ovina, Poa annua, Carex parva, and other herbaceous plants. The two ecosystems (meadow and shrubland) were about $1 \mathrm{~km}$ apart and were both near the Haibei station.

\subsection{Experiment design and soil sampling}

The soil samples were collected in the early growing season (Early), middle growing season (Middle), and late growing season (Late) of 2017 on May 1, August 3, September 23, respectively. Soil samples were collected using a soil corer with a diameter of $5 \mathrm{~cm}$ from six layers of the soil profile (0-10, 10-20, 20-30, 30-50, 50-70, 70-100 cm) from adjacent plots (3 by $3 \mathrm{~m}$, with $>5 \mathrm{~m}$ buffer, 4 replicates) of each ecosystem. Soil samples collected from two soil cores in one plot were mixed into one composite soil sample. Then fresh soil samples were stored at $4^{\circ} \mathrm{C}$ using a closed cooler covered with ice-bags and taken back to the laboratory within $24 \mathrm{~h}$ after each sampling. Visible stones were discarded and roots were picked when all soil samples were sieved through $2 \mathrm{~mm}$ sieve. The roots were dried at $65^{\circ} \mathrm{C}$ to constant weight and weighed to obtain belowground biomass (BGB) at different soil layers. The sieved soil samples were divided into three parts: one was air-dried for elements concentration and carbon $(\mathrm{C})$ and nitrogen $(\mathrm{N})$ isotope analysis; one was stored at $4^{\circ} \mathrm{C}$ for soil properties and microbial biomass; the other one was stored at $-20^{\circ} \mathrm{C}$ for soil extracellular enzyme activity analysis.

\subsection{Soil properties analysis}

Soil $\mathrm{pH}$ was determined in the suspension (1:5, the ratio of soil to water) after shaking at $200 \mathrm{r} \mathrm{min}^{-1}$ for $30 \mathrm{~min}$ with a $\mathrm{pH}$ meter (S210 SevenCompact ${ }^{\mathrm{TM}}$, Mettler-Toledo, Switzerland). Gravimetric soil water content (SWC) was obtained by drying at $105^{\circ} \mathrm{C}$ for $48 \mathrm{~h}$. Soil samples were treated with $1 \mathrm{M}$ hydrochloric acid $(\mathrm{HCl})$ to remove carbonate and then washed to neutrality with deionized water. Then, the concentration and isotope value of soil organic carbon (SOC) and total nitrogen (TN) were only measured once in the late growing season of 2017 (Fig. S4) because there should be little change in these values within several months of the same year (Boerner et al., 2005). SOC, TN, $\delta^{13} \mathrm{C}$ and $\delta^{15} \mathrm{~N}$ were determined through the Isotope-Ratio Mass Spectrometer (IRMS, Isoprime 100, Stockport, UK) coupled with an Elementary Analyzer (Elementar vario, Langenselbold, Germany). The ammonium nitrogen $\left(\mathrm{NH}_{4}{ }^{+}-\mathrm{N}\right)$ and nitrate nitrogen $\left(\mathrm{NO}_{3}{ }^{-} \mathrm{N}\right)$ were extracted with $2 \mathrm{M} \mathrm{KCl}$ solution in a soil-to-water ratio of 1:5 by shaking at $200 \mathrm{r} \mathrm{min}^{-1}$ for $30 \mathrm{~min}$ and filtered through filter paper. Then the $\mathrm{NH}_{4}{ }^{+}-\mathrm{N}$ and $\mathrm{NO}_{3}{ }^{-}-\mathrm{N}$ concentrations of filtered solution were determined by a Continuous Flow Analyzer (AA3, Bran + Luebbe, Germany). Extractable organic carbon (EOC) and extractable total nitrogen (ETN) were extracted with $0.5 \mathrm{M} \mathrm{K}_{2} \mathrm{SO}_{4}$ solution in a soil-to-water ratio of $1: 4$ by shaking at $200 \mathrm{r} \mathrm{min}^{-1}$ for $30 \mathrm{~min}$, filtered through filter paper, and analyzed by a TOC analyzer (Multi N/C 3100, Analytik Jena, Germany). Soil microbial biomass carbon (MBC) and nitrogen (MBN) were determined by the chloroform-fumigation-extraction method (Vance et al., 1987) with the extraction efficiency coefficient 0.45 (Jenkinson et al., 2004).

\subsection{Soil extracellular enzyme activity analysis}

The frozen soil samples stored at $-20^{\circ} \mathrm{C}$ were placed into $4^{\circ} \mathrm{C}$ for 5 days in order to reactivate soil microbes before assaying soil extracellular enzyme activity by 96 -well microplate method. Three soil hydrolytic enzymes involved in carbon cycling (BG, $\beta-1$, 4-glucosidase), nitrogen cycling (NAG, $\beta-1$, 4-N-acetyl-glucosaminnidase) and phosphorous cycling (NP, neutral phosphatase) were determined. The incubation time was $3 \mathrm{~h}$ and the Tris buffer $\mathrm{pH}$ (8.0) was close to the average $\mathrm{pH}$ of all soil samples (7.8). The 96-well microplates were quantified to get fluorescence for enzymes by a microplate reader (Synergy H1M, Biotek, USA). For more details, see Jing et al. (2017) and Chen et al. (2018).

\subsection{Data analysis}

All the analyses were performed using the $\mathrm{R}$ platform [version 3.5.3] (R Development Core Team, 2018). The vector analysis of soil enzymatic stoichiometry was used to measure the relative limitation of carbon and nutrients for soil microbes (Moorhead et al., 2013, 2016). Thus, the vector length shows the relative $C$ vs nutrient limitation, while the vector angle shows the relative $\mathrm{P}$ vs $\mathrm{N}$ limitation (Jing et al., 2020). 
First, the variations of soil properties ( $\mathrm{pH}, \mathrm{SWC}, \mathrm{EOC}, \mathrm{ETN}$, $\mathrm{NH}_{4}{ }^{+}-\mathrm{N}$ and $\mathrm{NO}_{3}{ }^{-}-\mathrm{N}$ ), root biomass (BGB), soil microbial biomass (MBC and MBN), soil extracellular enzyme activities (BG, NAG and NP) and their vector properties (length and angle) among two ecosystem types, six soil depths and three sampling times of the growing season in 2017 were obtained by linear mixed-effects models (Ime) (Table 1). The ecosystems types, soil depths and sampling times were designed as fixed factors. The Ime models were fitted by the Ime function of 'nlme' package. As the focus of this study was the seasonal variations of root and soil variables along the soil profile which were quite similar between the two ecosystems (as indicated by the mixed-effects models, Table 1), we plotted the average values (and standard errors) of the eight combined samples of both ecosystems to more clearly show the seasonal and vertical patterns (Figs. 1-3, S4).

Further, the effects of sampling time on all variables at each soil depth were determined by ANOVA (Figs. 1-3). The effects of soil depth on SOC, $\delta^{13} \mathrm{C}, \mathrm{STN}, \delta^{15} \mathrm{~N}$ and $\mathrm{C} / \mathrm{N}$ measured in the late growing season were also determined by ANOVA (Fig. S4). Asterisks indicate statistically significant differences between different sampling times or soil depths $\left({ }^{*} P<0.05\right.$, ** $P<0.01$, *** $P<0.001)$.

Finally, the principal components analysis (PCA) was used to assess the effects of sampling time on soil properties, root biomass, microbial biomass, and extracellular enzymes at different soil depths (Fig. 4). The PCA analysis was run by the prcomp function of 'ggbiplot' package. In addition, the Pearson correlation analysis was used to investigate the relationships among soil properties, root biomass, microbial biomass, and extracellular enzyme activities $\left({ }^{*} P<0.05\right.$, ${ }^{* *} P<0.01,{ }^{* * *} P<0.001$ ) (Fig. 5).

\section{Results}

3.1 Climatic conditions and soil microclimates at different depths

Both daily air temperature and monthly precipitation showed a humped curve from April to October in 2017 (Fig. S1). During this period, the maximum air temperature was $17.6^{\circ} \mathrm{C}$ in late July, while the minimum air temperature was $-5.4^{\circ} \mathrm{C}$ in early April. The mean monthly air temperature was $4.4^{\circ} \mathrm{C}$ in May (Early), $12.0^{\circ} \mathrm{C}$ in August (Middle) and $6.3^{\circ} \mathrm{C}$ in September (Late). During this period, the maximum monthly precipitation was $115.8 \mathrm{~mm}$ in July, and the minimum monthly precipitation was $42.4 \mathrm{~mm}$ in October. The mean monthly precipitation in

Table 1 Responses of soil properties, root and microbial biomass, and soil extracellular enzyme activities in two alpine ecosystems (meadow and shrubland) at different soil depths (0-10, 10-20, 20-30, 30-50, 50-70 and 70-100 cm) and different sampling times in 2017 (Early, Middle and Late growing season).

\begin{tabular}{|c|c|c|c|c|c|c|c|c|}
\hline & Variables & Season & Depth & Ecosystem & $\begin{array}{l}\text { Season } \times \\
\text { depth }\end{array}$ & $\begin{array}{l}\text { Season } \times \\
\text { ecosystem }\end{array}$ & $\begin{array}{l}\text { Depth } \times \\
\text { ecosystem }\end{array}$ & $\begin{array}{l}\text { Season } \times \\
\text { depth } \times \\
\text { ecosystem }\end{array}$ \\
\hline \multirow[t]{6}{*}{ Soil properties } & $\mathrm{pH}$ & ** & $* * *$ & $* * *$ & & & * & \\
\hline & SWC & $* *$ & $* * *$ & $* * *$ & & & $* * *$ & \\
\hline & EOC & $* *$ & $* \star *$ & * & & & & \\
\hline & ETN & & $* * *$ & & & * & & \\
\hline & $\mathrm{NH}_{4}{ }^{+}-\mathrm{N}$ & $* * *$ & $* * *$ & & & & & \\
\hline & $\mathrm{NO}_{3}{ }^{-}-\mathrm{N}$ & $* * *$ & $* \star *$ & $\star \star * *$ & $* * *$ & & $* * *$ & \\
\hline \multirow{3}{*}{$\begin{array}{l}\text { Root and microbial } \\
\text { biomass }\end{array}$} & Root biomass & $* * *$ & $* * *$ & * & $* * *$ & & & \\
\hline & $\mathrm{MBC}$ & $* * *$ & $* \star *$ & & $* * *$ & & & \\
\hline & MBN & $* * *$ & $* * *$ & & $* * *$ & & & \\
\hline \multirow{5}{*}{$\begin{array}{l}\text { Soil extracellular } \\
\text { enzymes }\end{array}$} & BG & & $* * *$ & * & $* * *$ & & $* * *$ & \\
\hline & NAG & & ** & & & & & \\
\hline & NP & $* * *$ & $* * *$ & & & * & & \\
\hline & Vector length & & * & & & & & \\
\hline & $\begin{array}{l}\text { Vector } \\
\text { angle }\end{array}$ & $* * *$ & $* *$ & & & $* *$ & & \\
\hline
\end{tabular}

This table shows the results of mixed effects model, and asterisks indicate statistically significant effects $\left({ }^{*} P<0.05,{ }^{* *} P<0.01,{ }^{* * *} P<0.001\right)$. SWC, soil water content; EOC, soil extractable organic carbon; ETN, soil extractable total nitrogen; MBC, soil microbial biomass carbon; MBN, soil microbial biomass nitrogen; BG, $\beta-1$, 4-glucosidase; NAG, $\beta-1$, 4-N-acetyl-glucosaminidase; NP, neutral phosphatase. 

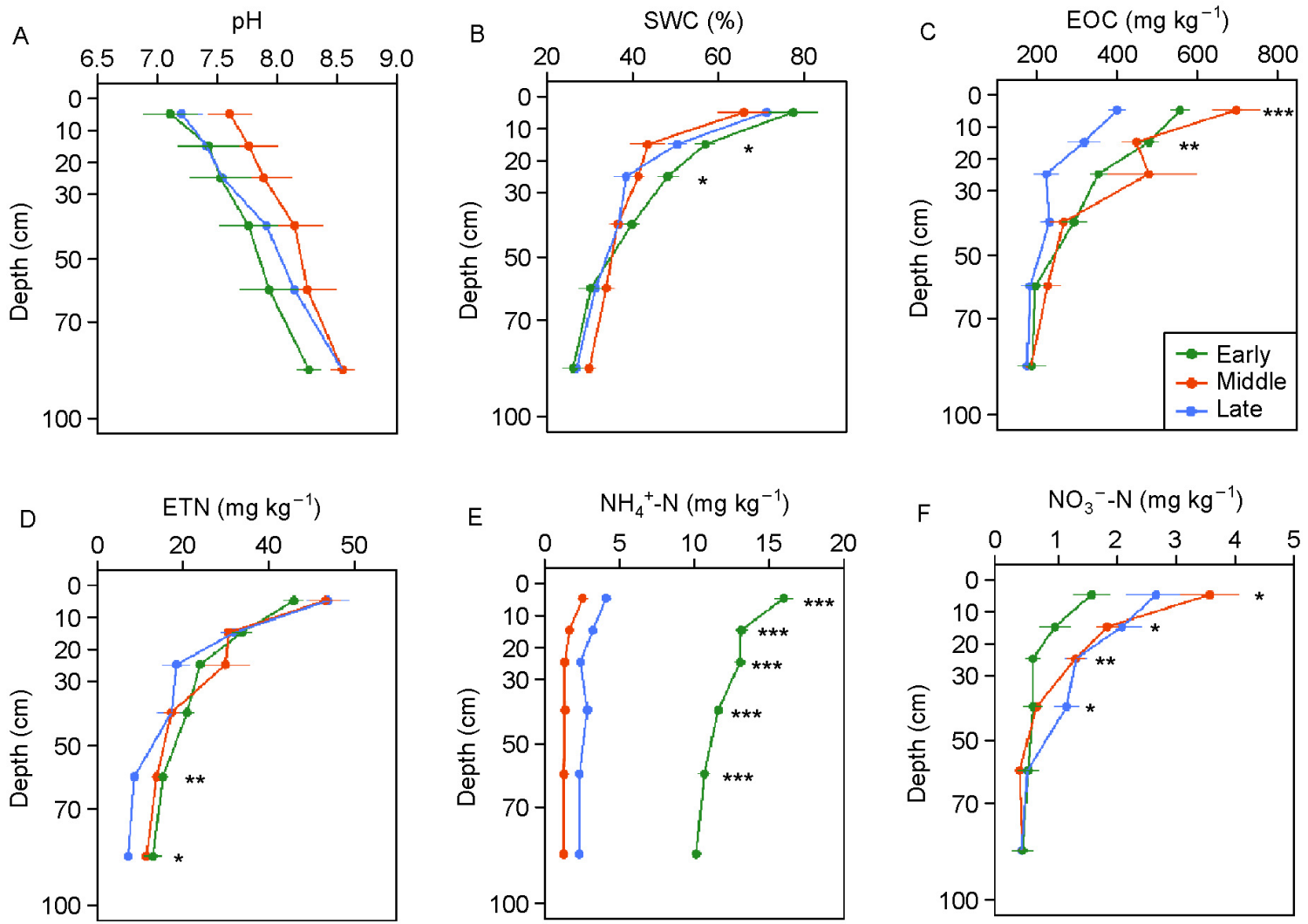

Fig. 1 Soil properties at different soil depths and different sampling times in 2017. (A) soil pH, (B) soil water content (SWC), (C) extractable organic carbon (EOC), (D) extractable total nitrogen (ETN), (E) ammonium nitrogen $\left(\mathrm{NH}_{4}{ }^{+}-\mathrm{N}\right)$, and (F) nitrate nitrogen $\left(\mathrm{NO}_{3}{ }^{-} \mathrm{N}\right)$. Different colors mean different times of the growing season. Early, early growing season. Middle, middle growing season. Late, late growing season. Points are mean \pm standard error $(n=8$, averaged across meadow and shrubland). Asterisks indicate statistically significant differences between different times of the growing season $\left({ }^{*} P<0.05,{ }^{* *} P<0.01,{ }^{* * *} P<0.001\right)$.
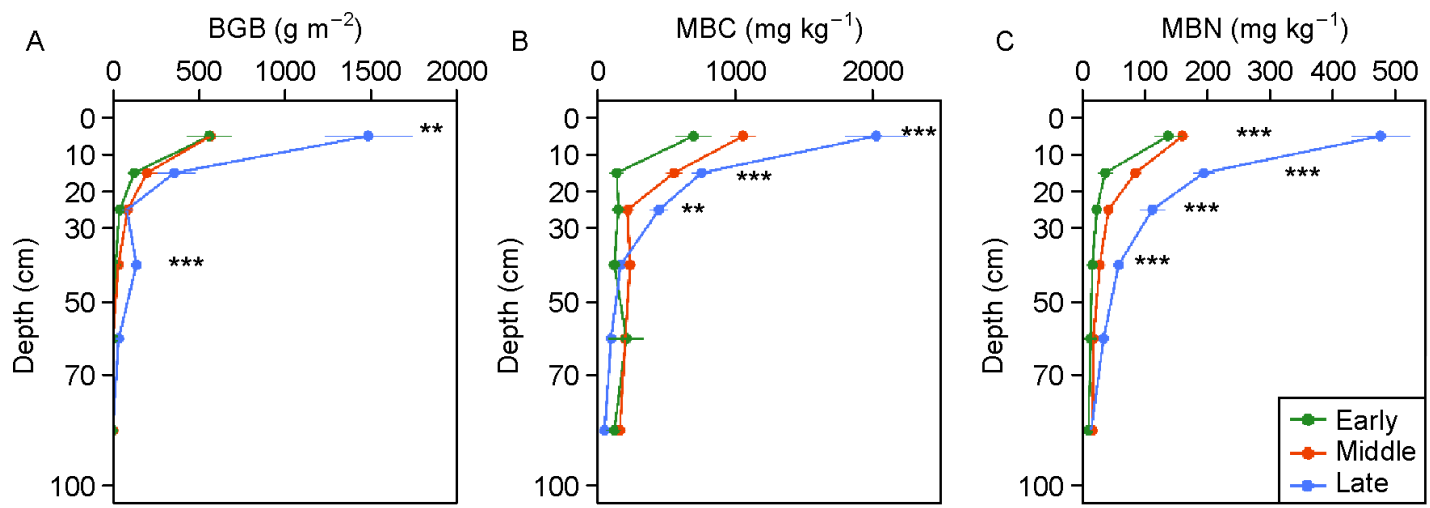

Fig. 2 Root and soil microbial biomass at different soil depths and different sampling times in 2017. (A) Plant belowground biomass (BGB), (B) soil microbial biomass carbon (MBC), and (C) soil microbial biomass nitrogen (MBN). Different colors mean different times of the growing season. Early, early growing season. Middle, middle growing season. Late, late growing season. Points are mean \pm standard error $(n=8$, averaged across meadow and shrubland). Asterisks indicate statistically significant differences between different times of the growing season $\left({ }^{*} P<0.05\right.$, $\left.{ }^{* *} P<0.01,{ }^{* \star *} P<0.001\right)$ 

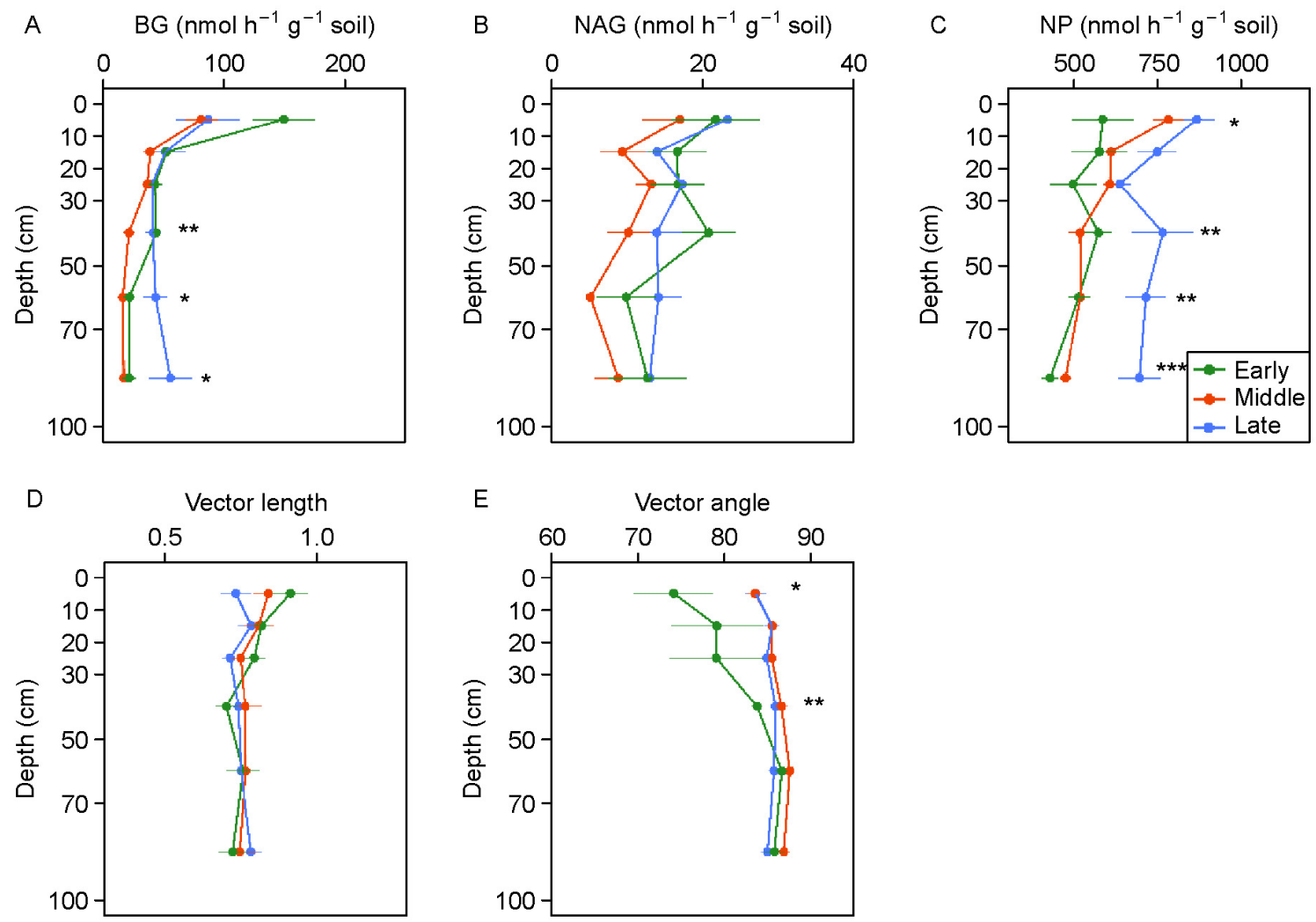

Fig. 3 Soil extracellular enzyme activities, and their vector lengths and angles at different soil depths and different sampling times in 2017. (A) $\beta$-1, 4-glucosidase (BG), (B) $\beta-1$, 4-N-acetyl-glucosaminidase (NAG), (C) neutral phosphatase (NP), (D) vector length, and $(E)$ vector angle. Different colors mean different times of the growing season. Early, early growing season. Middle, middle growing season. Late, late growing season. Points are mean \pm standard error $(n=8$, averaged across meadow and shrubland). Asterisks indicate statistically significant differences between different times of the growing season $\left({ }^{*} P<0.05\right.$, $\left.{ }^{* *} P<0.01,{ }^{* * *} P<0.001\right)$.

Early, Middle and Late growing season (i.e., the three sampling times) was $83.6 \mathrm{~mm}, 115.8 \mathrm{~mm}$ and $85.8 \mathrm{~mm}$ respectively.

According to our measurement of soil temperature at eight different soil depths $(5,10,20,30,40,60,80$ and $100 \mathrm{~cm})$ of alpine meadow in the growing season of 2018 , soil temperature of the profile showed a humped curve from June to October (Fig. S2). In general, soil temperature decreased with increasing soil depth, and the mean soil temperature had the maximum values at $5 \mathrm{~cm}$ depth and the minimum values at $100 \mathrm{~cm}$ depth. However, after early September, the temperature of subsurface soils $(30,40,60,80$ and $100 \mathrm{~cm})$ showed a convergent pattern. Therefore, the temporal patterns of soil temperature during the growing season varied with soil depth. Specifically, the temperature of surface soils $(5,10$ and $20 \mathrm{~cm})$ had larger temporal fluctuation during the growing season compared with the temperature of subsurface soils $(30,40$, 60,80 and $100 \mathrm{~cm}$ ).

We also measured soil moisture at six different soil depths $(10,20,30,40,60$ and $100 \mathrm{~cm})$ of alpine meadow from June to October, 2018 (Fig. S3). Interestingly, soil moisture showed somewhat different patterns compared with soil temperature. Volumetric soil water content declined with depth from 10 to
$40 \mathrm{~cm}$, and then increased from 40 to $100 \mathrm{~cm}$. Moreover, the water content of surface soils $(10$ and $20 \mathrm{~cm}$ ) varied greatly with time during the growing season, likely following rainfall events. However, the water content of deep soils (30, 40, 60 and $100 \mathrm{~cm}$ ) were relatively stable throughout the growing season.

\subsection{Plant and soil properties}

Most of the plant and soil properties were affected by season, and soil depth had strong effect on all plant and soil properties in both ecosystems, while a few plant and soil properties were affected by ecosystem (Table 1). All plant and soil properties had the same pattern that they decreased with increasing soil depth in all three seasons, except soil pH (Figs. 1, 2A). Soil pH increased with depth in all seasons, but did not vary significantly with season at all soil depths (Fig. 1A). Season, depth, and ecosystem had significant effects on soil water content (SWC, Table 1) which had maximum values in the early growing season and varied strongly across seasons in surface soils $(10-30 \mathrm{~cm})$ (Fig. 1B). Season, depth and their interaction, and ecosystem had significant effects on belowground biomass (BGB, Table 1) which had maximum values in 
A

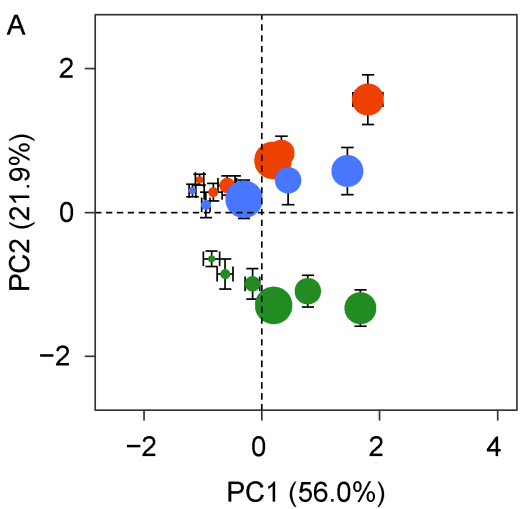

C
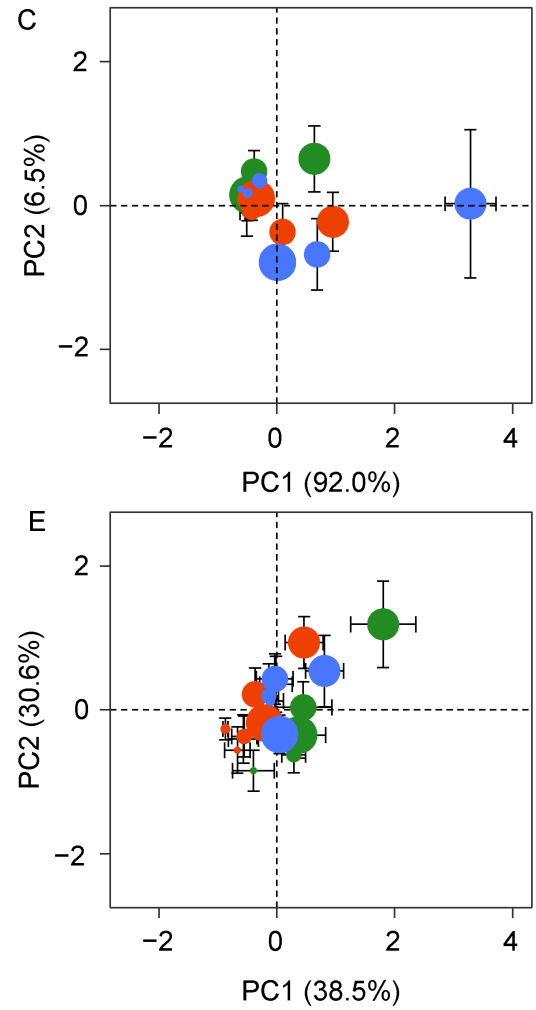

B

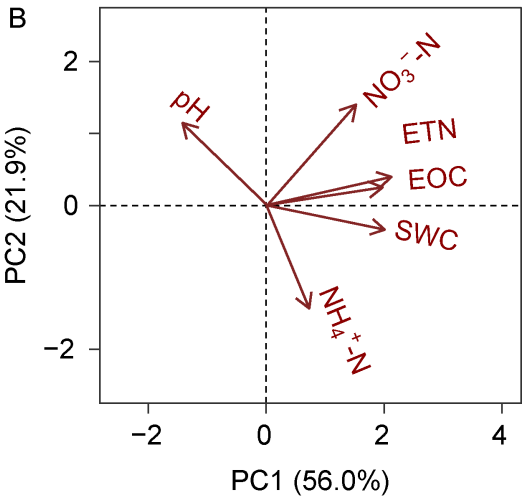

D

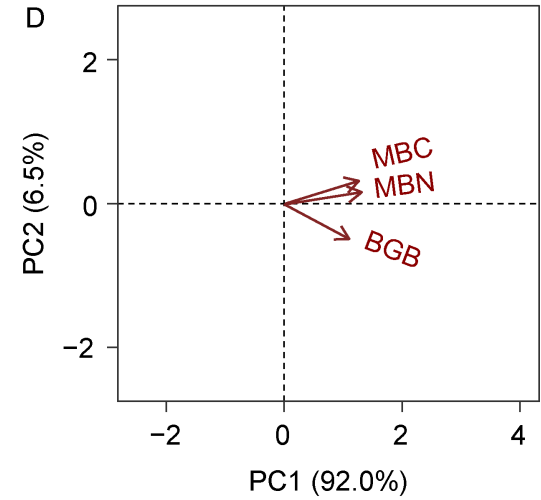

$\mathrm{F}$

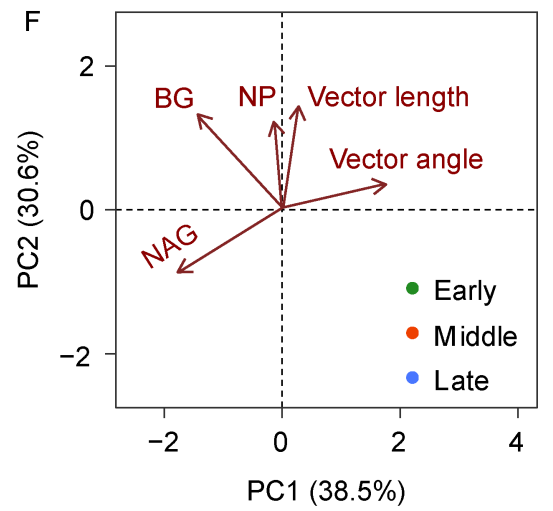

Fig. 4 Principal components analysis (PCA) of soil properties (A, B), root and microbial biomass (C, D), and soil extracellular enzyme activities $(E, F)(A, C, E$ are mean \pm standard error, $n=8)$ at different soil depths and different sampling times in 2017. Different colors mean different times of the growing season. Different size of points mean different soil depths. Early, early growing season. Middle, middle growing season. Late, late growing season.

the late growing season (Fig. 2A). Extractable organic carbon (EOC) was affected by season, depth and ecosystem (Table 1). EOC varied significantly across seasons in surface soils $(0-20 \mathrm{~cm})$, and had greatest values in the middle growing season (Fig. 1C). However, ETN was only affected by depth and varied significantly across seasons in deep soils (50-100 $\mathrm{cm}$ ) compared with surface soils (Table 1). Ammonium nitrogen $\left(\mathrm{NH}_{4}{ }^{+} \mathrm{N}\right)$ was strongly affected by season and depth, while nitrate nitrogen $\left(\mathrm{NO}_{3}{ }^{-} \mathrm{N}\right)$ was strongly affected by season, depth, their interaction, and ecosystem (Table 1). $\mathrm{NH}_{4}{ }^{+} \mathrm{N}$ in all soil depths and $\mathrm{NO}_{3}{ }^{-} \mathrm{N}$ in surface soils
$(0-50 \mathrm{~cm})$ varied significantly with season (Fig. 1E, 1F). For $\mathrm{NH}_{4}{ }^{+} \mathrm{N}$, the maximum values were in the early growing season and the minimum values were in the middle growing season (Fig. 1E).

Moreover, $\mathrm{pH}, \mathrm{SWC}$, EOC, ETN, $\mathrm{NO}_{3}{ }^{-}-\mathrm{N}$ and $\mathrm{NH}_{4}{ }^{+}-\mathrm{N}$ of soils were used to indicate soil properties with PCA. According to the PCA results, soil properties changed significantly with season (Fig. 4A). Soil pH, SWC, EOC, ETN and $\mathrm{NO}_{3}{ }^{-} \mathrm{N}$ were more associated with $\mathrm{PC} 1$ that explained $56.0 \%$ of total variation, while $\mathrm{NH}_{4}{ }^{+}-\mathrm{N}$ was more related to PC2 that explained $21.9 \%$ of total variation (Fig. 4B). Interestingly, soil 


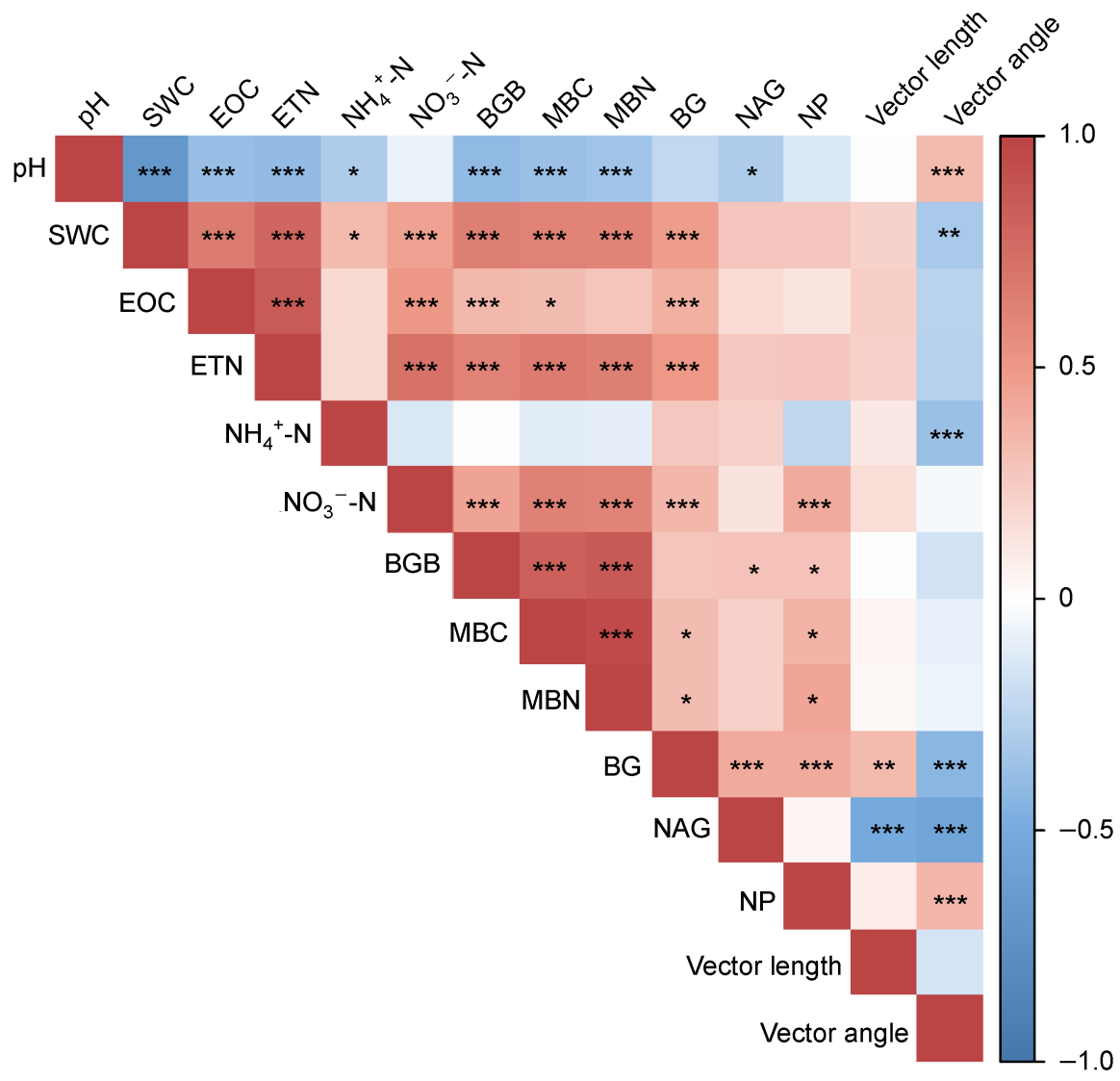

Fig. 5 5Pearson correlations between soil properties, root and microbial biomass, and soil extracellular enzyme activities ( ${ }^{*} P<0.05,{ }^{* *} P<0.01,{ }^{* * *} P<0.001$ ). SWC, soil water content; EOC, soil extractable organic carbon; ETN, soil extractable total nitrogen; BGB, plant belowground biomass; MBC, soil microbial biomass carbon; MBN, soil microbial biomass nitrogen; BG, $\beta$-1,4-glucosidase; NAG, $\beta-1,4-N$-acetyl-glucosaminidase; NP, neutral phosphatase.

$\mathrm{pH}$ had a negative relationship with other soil properties (Fig. 4B).

Soil depth had significant effect on soil organic carbon (SOC), total nitrogen (TN), SOC to TN ratio $(\mathrm{C} / \mathrm{N}), \delta^{13} \mathrm{C}$ and $\delta^{15} \mathrm{~N}$ (Fig. S4). Soil nutrients, such as SOC and TN, declined with increasing soil depth (Fig. S4a, S4b). But, soil $\delta^{13} \mathrm{C}$ increased with soil depth (Fig. S4c). Soil $\delta^{15} \mathrm{~N}$ showed a different pattern compared with soil $\delta^{13} \mathrm{C}$, increasing first and then declining with soil depth (Fig. S4d). Soil $\mathrm{C} / \mathrm{N}$ had the same pattern with SOC and TN (Fig. S4e).

\subsection{Soil microbial biomass and enzyme activity}

The effects of season, depth and their interaction on soil microbial biomass carbon (MBC) and nitrogen (MBN) were highly significant $(P<0.001$, Table 1$)$. Both MBC and MBN decreased with soil depth and had the maximum values in Late growing season, followed by Middle growing season and Early growing season (Fig. 2B, 2C). Additionally, they varied significantly with season in surface soils, especially at 0-30 $\mathrm{cm}$ for soil MBC and 0-50 cm for soil MBN (Fig. 2).

All soil enzymes (BG, NAG and NP) were affected by depth, while only NP was affected by season (Table 1). Activities of all soil enzymes decreased with soil depth, but did not vary with season at most of the soil depths except BG in deep soils $(30-100 \mathrm{~cm})$ and NP in surface $(0-10 \mathrm{~cm})$ and deep soils $(30$ $100 \mathrm{~cm}$ ) (Fig. 3).

The vector lengths of soil enzymes did not change with season or ecosystem (Table 1), suggesting that the relative $C$ vs nutrient limitation for soil microbes did not change significantly with season or ecosystem (Fig. 3D). In contrast, the vector angles of soil enzymes were significantly affected by season and depth, and the interaction of season and ecosystem (Table 1). Vector angles increased with soil depth, implying that the relative $\mathrm{P}$ vs $\mathrm{N}$ limitation for soil microbes increased with soil depth (Fig. 3E).

$B G B, M B C$ and $M B N$ were used to indicate root and microbial biomass. The PCA results suggested that root and microbial biomass changed with season (Fig. 4C). BGB, MBC and $\mathrm{MBN}$ were more related to $\mathrm{PC} 1$ which explained $92.0 \%$ of total variation, while $\mathrm{PC} 2$ explained $6.5 \%$ of total variation (Fig. 4C, 4D). Moreover, BG, NAG, NP, vector length, and vector angle were used to represent soil extracellular enzymes with PCA. According to the PCA results, soil extracellular enzymes and their vector properties did not change significantly with season (Fig. 4E). BG, NAG, and 
vector angle were more related to PC1 which explained $38.5 \%$ of total variation, while NP and vector length were more associated with $\mathrm{PC} 2$ that explained $30.6 \%$ of total variation (Fig. 4E, 4F).

\section{Discussion}

We originally expected that soil properties would vary with season because climate (mainly temperature and precipitation) and plant inputs vary greatly with season in these two alpine ecosystems. Unsurprisingly, our results showed significant variations in soil properties across the three sampling times during the growing season in these alpine ecosystems (Figs. 1, 5A). Also, we expected that root biomass, soil microbial biomass, and soil extracellular enzyme activities would vary significantly with season given large seasonal changes in climate and soil properties (Fig. S1). We found that root biomass and microbial biomass increased with time during the growing season (Figs. 2, 5C), but soil enzyme activities did not change significantly with time at all soil layers (Figs. 3, 4, 5E). Moreover, we hypothesized that the seasonal variations of soil properties, root and microbial biomass, and extracellular enzyme activities would progressively decline with soil depth, because the seasonal variations of driving factors (e.g., soil temperature, soil moisture and plant inputs) also decline with soil depth. Our results largely support this hypothesis as most of the soil and microbial variables (except enzyme-related variables) had larger seasonal variations in surface soils compared with those in subsurface soils (Figs. 1-4). Collectively, these results showed that most of soil properties and root and microbial biomass (but not enzyme activities and related variables) varied significantly with season and depth in alpine ecosystems. Moreover, the seasonal variations of these soil properties were generally stronger in surface soils than in subsurface soils.

\subsection{Changes in soil properties with depth and season}

In this study, we determined the effects of soil depth, sampling season and their interaction on soil properties in both alpine meadow and shrubland ecosystems. Consistent with the large variations in soil temperature and moisture with depth (Figs S2, S3), we observed that most of the soil properties changed significantly with depth (Fig. 1, Table 1). Most of soil properties had decreasing trends with soil depth (Fig. 1, S4), while pH and $\delta^{13} \mathrm{C}$ had increasing trends with soil depth. These results were largely consistent with previous studies in various grassland and forest ecosystems (e.g., Stone et al., 2014; Tian et al., 2017; Pries et al., 2018; Hou et al., 2019).

According to the PCA results, soil properties significantly varied with season (Fig. 5A, 5B). This result was consistent with our first hypothesis, likely attributed to the variations in air temperature and precipitation (Fig. S1) as well as soil temperature and moisture (Figs. S2, S3) over the growing season. In addition, EOC peaked in the middle growing season in surface soils (Fig. 1C), possibly due to the input of root exudates to stimulate microbial decomposition and nitrogen mining (Zhu et al., 2014; Yin et al., 2018). Soil available nitrogen $\left(\mathrm{NH}_{4}{ }^{+}-\mathrm{N}\right.$ and $\left.\mathrm{NO}_{3}{ }^{-} \mathrm{N}\right)$ also varied significantly with season (Table 1). Specifically, $\mathrm{NH}_{4}{ }^{+}-\mathrm{N}$ varied with season throughout the soil profile (Fig. 1E), while $\mathrm{NO}_{3}{ }^{-}-\mathrm{N}$ varied with season only in $0-50 \mathrm{~cm}$ (Fig. 1F). Among these soil labile pools of $\mathrm{C}$ and $\mathrm{N}, \mathrm{NH}_{4}{ }^{+}-\mathrm{N}$ showed the largest seasonal variation, being 3-4 times higher in early vs middle and late growing season (Fig. 1E). This flush of available $\mathrm{N}$ in soil after thawing in early spring is likely associated with the turnover of microbial community due to rapid changes in microclimate in early spring of alpine ecosystems (Bardgett et al., 2005). This phenomenon has been observed in other alpine and arctic ecosystems (Schmidt et al., 2007; Sistla and Schimel, 2013). As soil $N$ availability was the vital limiting factor to plant growth in alpine ecosystems (Agren et al., 2012; Kiba and Krapp, 2016), the flush of labile $\mathrm{N}$ and the increase of temperature and light after thawing should stimulate plant growth and biomass accumulation in these alpine ecosystems (Wang et al., 2020a).

4.2 Changes in root and soil microbial biomass, and enzyme activities with depth and season

We found that root and soil microbial biomass, and enzyme activities significantly changed (mostly decreased) with soil depth (Table 1, Figs. 2, 3). At this site, soil temperature progressively declined with soil depth during the growing season (Fig. S2), and soil water content declined from 10 to 40 $\mathrm{cm}$ and then increased to $100 \mathrm{~cm}$ during the growing season (Fig. S3). Moreover, soil properties (such as total and labile C and $\mathrm{N}$ concentration) and root biomass declined with soil depth (Fig. 1). Therefore, it is not surprising that root biomass and soil microbial biomass (MBC and MBN) both declined rapidly with soil depth (Fig. 2), which was consistent with most of the previous studies in forest and grassland ecosystems (e.g., Stone et al., 2014; Pries et al., 2018; Hou et al., 2019). Moreover, soil enzyme activities also declined greatly with soil depth (Fig. 3A-C). This result is also consistent with previous studies on the vertical pattern of soil enzyme activities (Stone et al., 2014; Peng and Wang, 2016; Jing et al., 2017). For example, Peng and Wang (2016) found that activities of BG, NAG and LAP all dramatically declined with soil depth (0-100 $\mathrm{cm}$ ) in temperate grassland ecosystems. In alpine ecosystems of this study, the vector length (microbial $C$ vs nutrient limitation) did not change significantly with soil depth, while the vector angle (microbial $N$ vs $P$ limitation) increased with soil depth. This result is consistent with the pattern reported in various forest ecosystems in eastern China (Jing et al., 2020).

Interestingly, we observed that the seasonal variation of microbial biomass (MBC and $\mathrm{MBN}$ ) progressively declined with soil depth (Fig. 2, Table 1), but the seasonal variations of most of soil enzymes (including total activity and vector variables) were relatively constant throughout the soil profile (Fig. 3, Table 1). This result was also confirmed by the PCA 
analysis (Fig. 4), and partly supported our second hypothesis. Not surprisingly, given large seasonal variations in climate, plant input and soil nutrient availability, soil microbial biomass showed large variations with time during the growing season, particularly in the top 0-30 cm (Fig. 2) (Bardgett et al., 1999). Additionally, soil MBC and MBN had maximum values in the late growing season, likely due to higher soil water content and plant input to soil (Devi and Yadava, 2006).

Yet, soil enzyme activities were little changed by season at different soil depths, while only NP was affected by season (Table 1). There were inconsistent results regarding the seasonal trends of soil enzymes among previous studies. For example, all enzyme activities had higher values in winter than in summer in Mediterranean ecosystems (Waldrop and Firestone, 2006). However, the activities of BG and NAG did not change with season in temperate forest and turfgrass ecosystems (Boerner et al., 2005; Yao et al., 2011). Despite their diverse sources and life cycles, measuring the potential activity of soil extracellular enzymes is a widespread method to characterize the potential ability of soil microbes for soil carbon and nutrient mineralization (Burns et al., 2013). In our study, we only detected minor seasonal variations in soil enzyme activities at various depths of the soil profile, suggesting that the potential enzymatic activity of soil microbial community remained largely stable over the growing season, despite significant changes in climate, soil properties, root and microbial biomass in these alpine ecosystems.

4.3 Controls of the seasonal dynamics in microbial biomass and enzyme activities along the soil profile

Pearson correlations were used to determine the relationships between soil properties (including $\mathrm{pH}$, SWC, EOC, ETN, $\mathrm{NH}_{4}{ }^{+}-\mathrm{N}$ and $\mathrm{NO}_{3}{ }^{-}-\mathrm{N}$ ), root and soil microbial biomass (including $\mathrm{BGB}, \mathrm{MBC}$ and $\mathrm{MBN}$ ), and soil extracellular enzyme activities (including BG, NAG, NP, vector length and vector angle). Soil $\mathrm{MBC}$ and $\mathrm{MBN}$ were closely correlated with most soil properties and BGB (Fig. 5). Soil enzymes (BG, NAG and NP) also showed some correlations with soil properties and microbial biomass (Fig. 5). Overall, soil properties were closely linked to soil microbial biomass and enzyme activities (but to a lesser degree) across three seasons and six depths in these alpine ecosystems (Fig. 5). This result was consistent with previous studies in forest ecosystems (e.g., Yang et al., 2010; Wang et al., 2020b). In this study, the large changes in climate, soil properties, and root biomass likely led to significant changes in microbial biomass (but not extracellular enzyme activity) during the growing season, and such seasonal variations appeared to diminish with increasing depth of the soil profile in these alpine ecosystems. Further studies should investigate the changes in microbial community composition and functioning (by amplicon sequencing or metagenomics) to better characterize the responses of soil microbial community to changes in biotic and abiotic variations over the growing season at various depths of the soil profile in these alpine ecosystems.

\section{Conclusion}

In this study, we investigated the changes in climate variables, soil properties and microbial community (biomass and enzyme activities) with time during the growing season for the whole soil profile of two alpine ecosystems on the Tibetan Plateau. The results showed that soil properties changed significantly with time and soil depth, likely due to changes in climate variables and plant inputs. Moreover, both root biomass and microbial biomass increased with time during the growing season and decreased with soil depth. However, microbial enzyme activities and vector properties mostly did not vary significantly with time or soil depth. Collectively, these results show that soil properties, microbial biomass and enzyme activities mostly decline with increasing depth of the soil profile, and soil properties and microbial biomass are generally more variable during the growing season than enzyme activities across the soil profile in these Tibetan alpine ecosystems. These results have important implications for better understanding whole-profile soil microbial activities and carbon dynamics of alpine ecosystems under climate change. Future studies could further investigate changes in microbial community composition and function by advanced techniques (e.g., amplicon sequencing, metagenomics) to better understand how changing environments affect whole-profile soil microbial communities and carbon dynamics in the alpine ecosystems on the Tibetan Plateau.

\section{Abbreviations}

$\mathrm{BGB}$, belowground biomass

SWC, soil water content

SOM, soil organic matter

SOC, soil organic carbon

$\mathrm{TN}$, total nitrogen

EOC, extractable organic carbon

ETN, extractable total nitrogen

$\mathrm{NH}_{4}{ }^{+}-\mathrm{N}$, ammonium nitrogen

$\mathrm{NO}_{3}{ }^{-}-\mathrm{N}$, nitrate nitrogen

$\mathrm{MBC}$, microbial biomass carbon

MBN, microbial biomass nitrogen

$B G, \beta-1,4-$ glucosidase

NAG, $\beta-1$, 4-N-acetyl-glucosaminnidase

NP, neutral phosphatase

\section{Acknowledgments}

We thank the staff at the Haibei station of Chinese Academy of Sciences for providing climate data and logistic support in the 
field. This study was financially supported by the National Natural Science Foundation of China (31971528 and 31988102). We also appreciate the constructive comments and suggestions from two anonymous reviewers that greatly improved this work.

\section{Electronic supplementary material}

Supplementary material is available in the online version of this article at https://doi.org/10.1007/s42832-021-0101-7 and is accessible for authorized users.

\section{References}

Agren, G.I., Wetterstedt, J.A.M., Billberger, M.F.K., 2012. Nutrient limitation on terrestrial plant growth-modeling the interaction between nitrogen and phosphorus. New Phytologist 194, 953-960.

Allison, S.D., Vitousek, P.M., 2004. Extracellular enzyme activities and carbon chemistry as drivers of tropical plant litter decomposition. Biotropica 36, 285-296.

Allison, S.D., Wallenstein, M.D., Bradford, M.A., 2010. Soil-carbon response to warming dependent on microbial physiology. Nature Geoscience 3, 336-340.

Balesdent, J., Basile-Doelsch, I., Chadoeuf, J., Cornu, S., Derrien, D., Fekiacova, Z., Hatte, C., 2018. Atmosphere-soil carbon transfer as a function of soil depth. Nature 559, 599-602.

Bardgett, R.D., Bowman, W.D., Kaufmann, R., Schmidt, S.K., 2005. A temporal approach to linking aboveground and belowground ecology. Trends in Ecology \& Evolution 20, 634-641.

Bardgett, R.D., Lovell, R.D., Hobbs, P.J., Jarvis, S.C., 1999. Seasonal changes in soil microbial communities along a fertility gradient of temperate grasslands. Soil Biology \& Biochemistry 31, 1021-1030.

Boerner, R.E.J., Brinkman, J.A., Smith, A., 2005. Seasonal variations in enzyme activity and organic carbon in soil of a burned and unburned hardwood forest. Soil Biology \& Biochemistry 37, 1419 1426.

Burns, R.G., DeForest, J.L., Marxsen, J., Sinsabaugh, R.L., Stromberger, M.E., Wallenstein, M.D., Weintraub, M.N., Zoppini, A., 2013. Soil enzymes in a changing environment: Current knowledge and future directions. Soil Biology \& Biochemistry 58, 216 234.

Chen, X., Ding, Z.J., Tang, M., Zhu, B., 2018. Greater variations of rhizosphere effects within mycorrhizal group than between mycorrhizal group in a temperate forest. Soil Biology \& Biochemistry $126,237-246$.

Chen, X., Hao, B.H., Jing, X., He, J.S., Ma, W.H., Zhu, B., 2019. Minor responses of soil microbial biomass, community structure and enzyme activities to nitrogen and phosphorus addition in three grassland ecosystems. Plant and Soil 444, 21-37.

Chen, Y., Feng, J.G., Yuan, X., Zhu, B., 2020. Effects of warming on carbon and nitrogen cycling in alpine grassland ecosystems on the Tibetan Plateau: A meta-analysis. Geoderma 370, 114363.

Chen, Y., Liu, X., Hou, Y.H., Zhou, S.R., Zhu, B., 2021. Particulate organic carbon is more vulnerable to nitrogen addition than mineral-associated organic carbon in soil of an alpine meadow. Plant and Soil 458, 93-103.
Devi, N.B., Yadava, P.S., 2006. Seasonal dynamics in soil microbial biomass $\mathrm{C}, \mathrm{N}$ and $\mathrm{P}$ in a mixed-oak forest ecosystem of Manipur, North-east India. Applied Soil Ecology 31, 220-227.

Dove, N.C., Arogyaswamy, K., Billings, S.A., Botthoff, J.K., Carey, C. J., Cisco, C., DeForest, J.L., Fairbanks, D., Fierer, N., Gallery, R. E., Kaye, J.P., Lohse, K.A., Maltz, M.R., Mayorga, E., Pett-Ridge, J., Yang, W.H., Hart, S.C., Aronson, E.L., 2020. Continental-scale patterns of extracellular enzyme activity in the subsoil: an overlooked reservoir of microbial activity. Environmental Research Letters 15, 1040a1.

Hou, Y.H., Chen, Y., Chen, X., He, K.Y., Zhu, B., 2019. Changes in soil organic matter stability with depth in two alpine ecosystems on the Tibetan Plateau. Geoderma 351, 153-162.

Jenkinson, D.S., Brookes, P.C., Powlson, D.S., 2004. Measuring soil microbial biomass. Soil Biology \& Biochemistry 36, 5-7.

Jing, X., Chen, X., Fang, J., Ji, C., Shen, H., Zheng, C., Zhu, B., 2020. Soil microbial carbon and nutrient constraints are driven more by climate and soil physicochemical properties than by nutrient addition in forest ecosystems. Soil Biology \& Biochemistry 141, 107657.

Jing, X., Chen, X., Tang, M., Ding, Z.J., Jiang, L., Li, P., Ma, S.H., Tian, D., Xu, L.C., Zhu, J.X., Ji, C.J., Shen, H.H., Zheng, C.Y., Fang, J.Y., Zhu, B., 2017. Nitrogen deposition has minor effect on soil extracellular enzyme activities in six Chinese forests. Science of the Total Environment 607, 806-815.

Kiba, T., Krapp, A., 2016. Plant nitrogen acquisition under low availability: Regulation of uptake and root architecture. Plant \& Cell Physiology 57, 707-714.

Kittredge, H.A., Cannone, T., Funk, J., Chapman, S.K., 2018. Soil respiration and extracellular enzyme production respond differently across seasons to elevated temperatures. Plant and Soil 425, 351-361.

Lal, R., 2004. Soil carbon sequestration impacts on global climate change and food security. Science 304, 1623-1627.

Moorhead, D.L., Rinkes, Z.L., Sinsabaugh, R.L., Weintraub, M.N., 2013. Dynamic relationships between microbial biomass, respiration, inorganic nutrients and enzyme activities: informing enzymebased decomposition models. Frontiers in Microbiology 4, 223.

Moorhead, D.L., Sinsabaugh, R.L., Hill, B.H., Weintraub, M.N., 2016. Vector analysis of ecoenzyme activities reveal constraints on coupled C, N and P dynamics. Soil Biology \& Biochemistry 93, 1-7.

Peng, X.Q., Wang, W., 2016. Stoichiometry of soil extracellular enzyme activity along a climatic transect in temperate grasslands of northern China. Soil Biology \& Biochemistry 98, 74-84.

Piao, S.L., Zhang, X.Z., Wang, T., Liang, E.Y., Wang, S.P., Zhu, J.T., Niu, B., 2019. Responses and feedback of the Tibetan Plateau's alpine ecosystem to climate change. Chinese Science Bulletin 64 , 2842-2855 (in Chinese).

Pries, C.E.H., Sulman, B.N., West, C., O'Neill, C., Poppleton, E., Porras, R.C., Castanha, C., Zhu, B., Wiedemeier, D.B., Torn, M.S., 2018. Root litter decomposition slows with soil depth. Soil Biology \& Biochemistry 125, 103-114.

R Development Core Team, 2018. R: A language and environment for statistical computing. R foundation for statistical computing, Vienna, Austria. https://www.R-project.org/.

Schmidt, M.W.I., Torn, M.S., Abiven, S., Dittmar, T., Guggenberger, G., 
Janssens, I.A., Kleber, M., Kogel-Knabner, I., Lehmann, J., Manning, D.A.C., Nannipieri, P., Rasse, D.P., Weiner, S., Trumbore, S.E., 2011. Persistence of soil organic matter as an ecosystem property. Nature 478, 49-56.

Schmidt, S.K., Costello, E.K., Nemergut, D.R., Cleveland, C.C., Reed, S.C., Weintraub, M.N., Meyer, A.F., Martin, A.M., 2007. Biogeochemical consequences of rapid microbial turnover and seasonal succession in soil. Ecology 88, 1379-1385.

Sihi, D., Inglett, P.W., Inglett, K.S., 2019. Warming rate drives microbial nutrient demand and enzyme expression during peat decomposition. Geoderma 336, 12-21.

Sinsabaugh, R.L., 2010. Phenol oxidase, peroxidase and organic matter dynamics of soil. Soil Biology \& Biochemistry 42, 391-404.

Sinsabaugh, R.L., Lauber, C.L., Weintraub, M.N., Ahmed, B., Allison, S.D., Crenshaw, C., Contosta, A.R., Cusack, D., Frey, S., Gallo, M. E., Gartner, T.B., Hobbie, S.E., Holland, K., Keeler, B.L., Powers, J. S., Stursova, M., Takacs-Vesbach, C., Waldrop, M.P., Wallenstein, M.D., Zak, D.R., Zeglin, L.H., 2008. Stoichiometry of soil enzyme activity at global scale. Ecology Letters 11, 1252-1264.

Sinsabaugh, R.L., Shah, J.J.F., 2012. Ecoenzymatic stoichiometry and ecological theory. Annual Review of Ecology, Evolution, and Systematics 43, 313-343.

Sistla, S.A., Schimel, J.P., 2013. Seasonal patterns of microbial extracellular enzyme activities in an arctic tundra soil: Identifying direct and indirect effects of long-term summer warming. Soil Biology \& Biochemistry 66, 119-129.

Stone, M.M., DeForest, J.L., Plante, A.F., 2014. Changes in extracellular enzyme activity and microbial community structure with soil depth at the Luquillo Critical Zone Observatory. Soil Biology \& Biochemistry 75, 237-247.

Stone, M.M., Kan, J.J., Plante, A.F., 2015. Parent material and vegetation influence bacterial community structure and nitrogen functional genes along deep tropical soil profiles at the luquillo critical zone observatory. Soil Biology \& Biochemistry 80, 273-282.

Stone, M.M., Weiss, M.S., Goodale, C.L., Adams, M.B., Fernandez, I. J., German, D.P., Allison, S.D., 2012. Temperature sensitivity of soil enzyme kinetics under $\mathrm{N}$-fertilization in two temperate forests. Global Change Biology 18, 1173-1184.

Tian, Q.X., Wang, X.G., Wang, D.Y., Wang, M., Liao, C., Yang, X.L., Liu, F., 2017. Decoupled linkage between soil carbon and nitrogen mineralization among soil depths in a subtropical mixed forest. Soil
Biology \& Biochemistry 109, 135-144.

Vance, E.D., Brookes, P.C., Jenkinson, D.S., 1987. An extraction method for measuring soil microbial biomass C. Soil Biology \& Biochemistry 19, 703-707.

Waldrop, M.P., Firestone, M.K., 2006. Seasonal dynamics of microbial community composition and function in oak canopy and open grassland soils. Microbial Ecology 52, 470-479.

Wang, H., Liu, H.Y., Cao, G.M., Ma, Z.Y., Li, Y.K., Zhang, F.W., Zhao, X., Zhao, X.Q., Jiang, L., Sanders, N.J., Classen, A.T., He, J.S., 2020a. Alpine grassland plants grow earlier and faster but biomass remains unchanged over 35 years of climate change. Ecology Letters 23, 701-710.

Wang, Y., Liu, X., Chen, F., Huang, R., Deng, X., Jiang, Y., 2020b. Seasonal dynamics of soil microbial biomass $\mathrm{C}$ and $\mathrm{N}$ of Keteleeria fortunei var. cyclolepis forests with different ages. Journal of Forestry Research 31, 2377-2384.

Xiao, W., Chen, X., Jing, X., Zhu, B., 2018. A meta-analysis of soil extracellular enzyme activities in response to global change. Soil Biology \& Biochemistry 123, 21-32.

Yang, K., Zhu, J.J., Zhang, M., Yan, Q.L., Sun, O.J., 2010. Soil microbial biomass carbon and nitrogen in forest ecosystems of northeast China: a comparison between natural secondary forest and larch plantation. Journal of Plant Ecology 3, 175-182.

Yang, Y.H., Fang, J.Y., Tang, Y.H., Ji, C.J., Zheng, C.Y., He, J.S., Zhu, B., 2008. Storage, patterns and controls of soil organic carbon in the Tibetan grasslands. Global Change Biology 14, 1592-1599.

Yao, H.Y., Bowman, D., Shi, W., 2011. Seasonal variations of soil microbial biomass and activity in warm- and cool-season turfgrass systems. Soil Biology \& Biochemistry 43, 1536-1543.

Yin, L.M., Dijkstra, F.A., Wang, P., Zhu, B., Cheng, W.X., 2018. Rhizosphere priming effects on soil carbon and nitrogen dynamics among tree species with and without intraspecific competition. New Phytologist 218, 1036-1048.

Zhang, R.H., Su, F.G., Jiang, Z.H., Gao, X.J., Guo, D.L., Ni, J., You, Q. L., Lan, C., Zhou, B.T., 2015. An overview of projected climate and environmental changes across the Tibetan Plateau in the 21st century. Chinese Science Bulletin 60, 3036-3047 (in Chinese).

Zhu, B., Gutknecht, J.L.M., Herman, D.J., Keck, D.C., Firestone, M.K., Cheng, W.X., 2014. Rhizosphere priming effects on soil carbon and nitrogen mineralization. Soil Biology \& Biochemistry 76, 183192. 